\title{
Effect of Altrenogest Feeding in Prepubertal Buffalo Heifers Vis-A-Vis Plasma Estrogen-Progesterone Levels and Biochemical Profile
}

\author{
A. S. Aulakh ${ }^{1 *}$, Prahlad Singh ${ }^{1}$, Gurpreet Singh $^{2}$, S. S. Dhindsa ${ }^{1}$, \\ M. Honparkhe ${ }^{1}$ and Arashdeep Kaur ${ }^{1}$
}

${ }^{1}$ Department of Veterinary Gynaecology and Obstetrics, Guru Angad Dev Veterinary and Animal Sciences University, Ludhiana, Punjab, India

${ }^{2}$ Department of Veterinary Physiology and Biochemistry, Guru Angad Dev Veterinary and Animal Sciences University, Ludhiana, Punjab, India

*Corresponding author

\section{A B S T R A C T}

\section{Keywords}

Altrenogest,

Buffalo, Heifers,

Hormonal levels,

Metabolic profile

\section{Article Info}

Accepted:

20 July 2020

Available Online:

10 August 2020
A comparative study to evaluate the effect of altrenogest feeding on blood metabolic and hormonal profiling of prepubertal buffalo heifers, $(n=20), 18-24$ months of age and 250-300 kg body weight. Buffalo heifers were divided into three groups; Group I: ( $n=7)$ was fed oral Altrenogest (a progestin analogue, Regumate ${ }^{\circledR}$, MSD, India, Ltd) at the rate $0.044 \mathrm{mg} / \mathrm{kg}$ body weight per day for 13 days

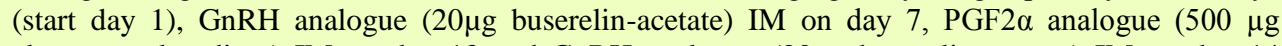

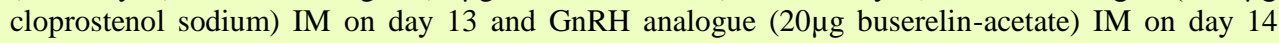
(modified ovsynch protocol), followed by FTAI on day15; Group II: $(n=7)$ administered modified ovsynch protocol, followed by FTAI on day15; Group III: Control group $(n=6)$. Plasma BUN, blood glucose, estrogen and progesterone hormones were estimated on $1,4,7,10,13$ and 15 day post altrenogest feeding. BUN concentrations across day 1 through day 10 differed nonsignificantly $(\mathrm{P}>0.05)$. Across day 13, 14 and 15 Group $1(4.6 \pm 0.49 \mathrm{mg} / \mathrm{dl})$ heifers had significantly $(\mathrm{P}<0.05)$ lower BUN concentration than Group $2(5.52 \pm 0.54 \mathrm{mg} / \mathrm{dl})$ and Group $3(7.13 \pm 0.33 \mathrm{mg} / \mathrm{dl})$. Significant differences $(\mathrm{P}<0.05)$ in mean plasma glucose levels were observed across day 10 and 15 in Group $1(61.08 \pm 1.93 \mathrm{mg} / \mathrm{dl})$, Group $3(56.83 \pm 0.41 \mathrm{mg} / \mathrm{dl})$ and Group $2(57.2 \pm 0.36 \mathrm{mg} / \mathrm{dl})$. Plasma Progesterone concentrations varied from 0.30 to $3.93 \mathrm{ng} / \mathrm{ml}, 0.40$ to $0.98 \mathrm{ng} / \mathrm{ml}$ and 0.70 to $0.94 \mathrm{ng} / \mathrm{ml}$ in Group 1, 2 and 3, respectively. Plasma progesterone in group 1 across days 4, 7, 10 and 13 differed significantly $(\mathrm{P}<0.05)$ from group 2 and 3.Plasma Estradiol varied from $26.32 \pm 0.46$ $\mathrm{pg} / \mathrm{ml}$ to $40.04 \pm 0.59 \mathrm{pg} / \mathrm{ml}, 25.42 \pm 0.37 \mathrm{pg} / \mathrm{ml}$ to $37.22 \pm 0.58 \mathrm{pg} / \mathrm{ml}$ and $33.41 \pm 0.41 \mathrm{pg} / \mathrm{ml}$ to $34.34 \pm 0.48 \mathrm{pg} / \mathrm{ml}$ in Group 1, 2 and 3, respectively. Across Day 15, Group 1 mean estradiol concentrations of $40.04 \pm 0.59 \mathrm{pg} / \mathrm{ml}$ were significantly higher $(\mathrm{P}<0.05)$ than mean estradiol concentrations of Group $2(37.22 \pm 0.58 \mathrm{pg} / \mathrm{ml})$ and Group $3(33.63 \pm 0.36 \mathrm{pg} / \mathrm{ml})$ on FTAI day. Estrogen-progesterone (EP) ratio taken as indicator of follicular growth on day 1 was $(37.56 \pm 1.46)$, $(38.75 \pm 0.82)$ and $(35.84 \pm 0.61)$ with respect to Group 1,2 and 3 respectively. Significant differences $(\mathrm{P}<0.05)$ were observed between Group $1(134.20 \pm 7.33)$, Group $2(91.74 \pm 3.55)$ and Group 3 (47.54 \pm 0.81 ) on Day 15 . EP ratio across day 4, 7, and 10 post treatment were significantly $(\mathrm{P}<0.05)$ lower in Group 1 and Group 2 than in Group 3 heifers. Results indicate that Altrenogest supplementation lowered BUN concentration and increased glucose concentration in prepubertal buffalo heifers. In altrenogest fed heifers the progesterone was higher in the luteal phase and the estrogen was elevated around estrous. The EP ratio was better in altrenogest fed prepubertal buffalo heifers. 


\section{Introduction}

Future of dairy activity depends on a successful program for raising and turning heifers into good milk producers, which should surpass the current milk production level in the herd. Buffalo plays a major role in India's agricultural economy and acts as the backbone for Indian dairy milk production. It contributes more than 60 percent of India's overall milk production. Buffalo is considered to be a poor reproductive performer, likely to show delayed puberty, poor estrus expression, longer postpartum anestrus cycle and poor conception rates (Das and Khan 2010), contributing to its low reproductive performance and reduces the calf production leading to economic losses. Making the buffaloes conceive at the right time remains a major concern for Buffalo breeders as well as for veterinarians. Age at the onset of puberty is an essential factor for making animals available at the appropriate time for breeding. Prepubertal anestrous impacts the productivity of an animal's lifespan due to delay in period between first calving and lactation.

Puberty, period of functionally developed sexual organs, is characterized by first ovulation and plasma progesterone concentrations above 1ng/ml (Evans et al., 1995). Many factors like species, genetic potentiality, plane of nutrition, growth, body weight, different hormones, health and other management conditions have a direct or indirect effect on growth, puberty and sexual maturity in animals. Body weight at early age has an important role on life time performance, including production and reproduction (Rauwa et al., 1998).

Buffalo heifers typically achieve puberty when they reach between 55 to 60 percent of their adult body weigh but the age of achieving puberty varies widely, varying from
18 to 46 months (Jainudeen and Hafez, 1993). Riverine buffalo heifers show first estrus at the age of 15-18 months and swamp buffaloes at 21-24 months (Borghese 2005). Average age of puberty in buffalo is estimated to be 37 months, whereas age at first calving in Nilli Ravi buffalo is 55 months (Bashir 2009). Buffalo heifers with average adult body weight of 450-500 kg can be first bred at around $270-300 \mathrm{~kg}$ body weight.

Pubertal age in buffalo can be reduced by 2 years, with improved diet and reproductive management (Hinglak 2013). Treatments for cyclicity induction in anestrous animals hastens the initiation of puberty by use of variety of exogenous hormones. GnRH-based regimens are beneficial for inducing cyclicity in delayed puberty buffalo heifers and those with lactational anestrous. The treatment of progestogen is an important way of treating anestrous. Progestogens have been effectively used in prepubertal heifers to induce cyclicity and appear more powerful when combined with higher dietary energy (Hinglak 2013).

Exogenous administration of progestogens such as Melengestrol Acetate (MGA), MAP, $\mathrm{CAP}$ and Altrenogest was reported to induce better synchronized estrus (Mapletoft et al., 2003). MGA administered for 7 days has demonstrated a decrease in breeding fertility and pregnancy rates of only 40 to 55 per cent (Patterson et al., 1989). A 31-day MGA dependent estrus synchronization protocol adds an additional estrous cycle prior to AI and higher pregnancy rates. In prepubertal heifers, MGA feeding induces cyclicity (Patterson et al., 1989). It is believed that Altrenogest, an oral progestin, is beneficial for induction of behavioral estrus in 64.3 percent cases (Hinglak, 2013), however, pregnancy rates (average: 35.7\%) after oral progesterone feeding remains highly variable (Clarence 2004). 
Altrenogest (allyltrenbolone, ALT) is an orally active progestin that has been developed for horse use. Altrenogest was chemically modified by adding a hydroxyl group and 3 carbon chain positioned at the progestin's carbon 17 (Peters, 1992). Research has shown that ALT has low anabolic activity and is 20 times less potent than testosterone or equivalent progestin relative to castrated rats for effects on muscle growth (Peters, 1992). It was further noted that 50 percent of the altrenogest residue is bound to binding proteins and is inactive biologically. Based on these results (Peters, 1992), the withdrawal time for equids for ALT (commercially known as Regumate) is 15 days.

There is no deleterious effects of ALT administration to healthy cycling mares when fed for 86 days at a rate of $0.044 \mathrm{mg}$ per $\mathrm{kg}$ body weight, $0.132 \mathrm{mg}$ per $\mathrm{kg}$ body weight, or $0.220 \mathrm{mg}$ per $\mathrm{kg}$ body weight (Shideler et al., 1983). ALT has been a widely used progestin in the mare over the past two decades (Squires et al., 1979, Webel and Squires 1982, Squires et al 1983), and the sow (Davis et al., 1979, Davis et al 1987, Martinat-Botte et al., 1985). ALT was found to safely and efficiently suppress behavioral estrus in mares when offered at 0.044 to $0.220 \mathrm{mg}$ per $\mathrm{kg}$ body weight (Shideler et al., 1983).ALT has been involved in the synchronization of estrus in cycling mares (Squires et al., 1979) and transitional mares (Turner et al., 1981, Webel and Squires 1982) when offered at a rate of $0.044 \mathrm{mg}$ per $\mathrm{kg}$ body weight.

There have been some reports that ALT has not completely blocked ovulation in all treated cycling or transitional mares (Squires et al., 1979, Turner et al., 1981, Webel and Squires 1982). The present study was taken up with the objective to assess hormonal and biochemical profiles in prepubertal buffalo heifers fed on altrenogest.

\section{Materials and Methods}

\section{Place of study}

Study was designed to determine the effect of altrenogest feeding vis-à-vis ovsynch regimen in prepubertal buffalo heifers. Work was carried out at private dairy farms in and around Ludhiana. Animals selected for this study were maintained under good housing, feeding and health managemental practices. The present experiment was carried out on 20 graded pre-pubertal Murrah buffalo heifers.

\section{Selection and management of buffaloes}

Buffalo heifers selected had a body condition score of $\geq 3$ on 5 scale. Heifers selected were 18 to 24 months of age with an average body weight of $250-300 \mathrm{~kg}$, housed in semiintensive housing systems and identified based on ear tags. They were fed green fodder or silage depending on the availability, wheat straw, concentrates and mineral mixture throughout the year. Fresh drinking water was provided ad libitum round the day.

\section{Study design}

Prepubertal buffalo heifers $\mathrm{n}=20, \quad 18-24$ months of age and $250-300 \mathrm{~kg}$ body weight were selected for the study and divided into three groups.

Group I: Heifers $(n=7)$ were fed oral Altrenogest at the rate $0.044 \mathrm{mg} / \mathrm{kg}$ body weight/day for 13 days (start day 1), an injection of GnRH analogue $(20 \mu \mathrm{g}$ Buserelinacetate,IM) was givenonday 7 and 14,PGF2 $\alpha$ analogue (500 $\mu \mathrm{g}$ Cloprostenol sodium, IM) was administered on day 13 followed by fixed time AI on day 15.

Group II: Heifers $(n=7)$ were administered

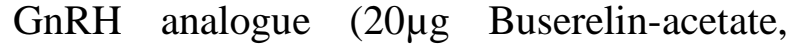
IM)on day 7 and 14, PGF2 $\alpha$ analogue (500 $\mu \mathrm{g}$ 
cloprostenol sodium, IM) on day 13 and fixed time A.I on day15.

Group III: Heifers (n=6) were not administered any drug and served as a control group.

\section{Collection of blood samples}

Blood samples were collected for estimation of blood urea nitrogen (BUN), blood glucose, plasma estradiol $\left(\mathrm{E}_{2}\right)$ and plasma progesterone $\left(\mathrm{P}_{4}\right)$ on day $1,4,7,10,13$ and 15. Estradiol 17 $\beta$ and progesterone were estimated using specific ELISA kits.

Blood samples were collected by jugular venipuncture into heparinized (1:1000) polystyrene tubes. Tubes were immediately placed in ice and transferred to the laboratory. Plasma was separated by centrifugation (3000 $\mathrm{rpm}, 15 \mathrm{~min}$ ), and stored at $-20^{\circ} \mathrm{C}$ until determination of hormones and biochemical parameters as per experiment protocol.

\section{Hormonal and metabolic profiling}

Progesterone and estradiol estimation was done using a solid phase enzyme immunoassay kits. ELISA kits used for P4 and E2 were manufactured by XEMA Co. Ltd (Moscow, Russia) with catalog number K207 and K208 respectively. The sensitivity of the progesterone and estradiol assay was 0.6 $\mathrm{ng} / \mathrm{ml}$ and $62.4 \mathrm{pg} / \mathrm{ml}$. Glucose and BUN level in blood was estimated by standard technique using Erba ${ }^{\circledR}$ Mannheim kit on fully automatic biochemistry analyzer.

\section{Statistical analysis}

Data obtained were expressed as Mean \pm SEM. Following analysis of variance, significant differences were detected by the T-test and ANOVA, followed by Duncan's multiple range test for post HOC comparison.
The results were supported with wilcoxon test (non-parametric) for the parameters suspected of any distribution other than normal distribution. All analyses were performed with the statistics package SAS VERSION 9.3 Copyright (C) 2011, SAS Institute Inc., North Carolina, USA.

\section{Results and Discussion}

\section{Plasma Blood Urea Nitrogen (BUN)}

BUN level (mg/dl) in pre-pubertal buffalo heifers supplemented with altrenogest in feed is presented as mean \pm SEM, in (Table 14). Concentration of BUN in prepubertal buffalo heifers, ranged from $(4.60 \pm 0.49$ to $7.24 \pm$ $0.42 \mathrm{mg} / \mathrm{dl}, 4.70 \pm 0.62$ to $7.08 \pm 0.95 \mathrm{mg} / \mathrm{dl}$ and $6.98 \pm 0.31$ to $7.23 \pm 0.32 \mathrm{mg} / \mathrm{dl}$ ) in Group 1, 2 and 3 respectively (Table 1). There were non-significant differences $(\mathrm{P}<0.05)$ in $\mathrm{BUN}$ concentration on day 1 through day 10 , whereas, on day 13 onwards the heifers fed altrenogest supplement indicated significantly $(\mathrm{P}<0.05)$ lower BUN concentrations than other two Groups. Arosh et al., (1998), in cyclic and anestrus cows reported similar findings. However, BUN levels in heifers as reported by Suiding (2013) were higher ( 7 to $26 \mathrm{mg} / \mathrm{dl}$ ) than present study, may be due to the heifers selected at an organized dairy farm having higher plane of protein in diet. Altrenogest fed prepubertal heifers along with modified Ovsynch protocol showing estrus response had initial BUN values of $(7.15 \pm$ $0.73 \mathrm{mg} / \mathrm{dl})$, on start of feeding which reduced to $(4.6 \pm 0.49 \mathrm{mg} / \mathrm{dl})$ on day 15 . Corresponding value in modified Ovsynch alone without altrenogest feeding were (6.61 $\pm 0.69 \mathrm{mg} / \mathrm{dl})$ on day 1 and $(4.70 \pm$ $0.62 \mathrm{mg} / \mathrm{dl}$ ) on day 15 (Table 1 ).

\section{Plasma glucose concentration}

Glucose concentration in prepubertal buffalo heifers, ranged from $(57.28$ to $61.08 \mathrm{mg} / \mathrm{dl}$, 
55.33 to $57.20 \mathrm{mg} / \mathrm{dl}$ and 56.81 to 57.30 $\mathrm{mg} / \mathrm{dl}$ ) in Group 1, 2 and 3, respectively (Table 2). Significant differences $(\mathrm{P}<0.05)$ in plasma mean glucose levels were observed across day 10 and 15 in altrenogest supplemented heifers in Group 1 and heifers in Group 3 (control) and Group 2. Altrenogest fed Group indicated a better glucose level and thus a promoter to early puberty in buffalo heifers. The findings of present study are in agreement with the observations of Ramadan et al2015. Glucose concentration in Group 1 increased from $(57.28 \pm 0.60 \mathrm{mg} / \mathrm{dl}$ on day 1 to $61.08 \pm 1.93 \mathrm{mg} / \mathrm{dl}$ ) on day 15 (Table 2 ).

\section{Plasma progesterone profile}

Plasma $\mathrm{P}_{4}$ profile at different days viz. Day 1 , $4,7,10,13$ and 15 of altrenogest feeding, varied from $(0.30 \pm 0.01$ to $3.93 \pm 0.05 \mathrm{ng} / \mathrm{ml}$, $0.40 \pm 0.01$ to $0.98 \pm 0.01 \mathrm{ng} / \mathrm{ml}$ and $0.70 \pm$ 0.01 to $0.94 \pm 0.01 \mathrm{ng} / \mathrm{ml}$ in Group 1,2 and 3 respectively (Table 3). Altrenogest fed prepubertal heifers subjected to modified Ovsynch program exhibiting estrus in Group $1(\mathrm{n}=7)$ had initial $\mathrm{P}_{4}$ concentration of $(0.90 \pm$ $0.03 \mathrm{ng} / \mathrm{ml})$, at the start of feeding increased to $(2.64 \pm 0.01 \mathrm{ng} / \mathrm{ml}, 3.15 \pm 0.06 \mathrm{ng} / \mathrm{ml}$, $3.60 \pm 0.10 \mathrm{ng} / \mathrm{ml}$ and $3.93 \pm 0.05 \mathrm{ng} / \mathrm{ml}$ ) on day $4,7,10$ and 13 , respectively and then reduced to $0.30 \pm 0.01 \mathrm{ng} / \mathrm{ml}$ on day 15 (Table 3). Progesterone concentration in modified Ovsynch alone (Group 2) without altrenogest feeding $(n=6)$ were $(0.89 \pm 0.01$ $\mathrm{ng} / \mathrm{ml}$ on day 1 and $0.40 \pm 0.01 \mathrm{ng} / \mathrm{ml}$ ) on day 15(Table 3). Control Group (Group 3, $n=6$ ) pre-pubertal buffalo heifers $\mathrm{P}_{4}$ concentration were $(0.94 \pm 0.01 \mathrm{ng} / \mathrm{ml}$ on day 1 and $0.70 \pm$ $0.01 \mathrm{ng} / \mathrm{ml}$ on day 15) (Table 3). The concentration of $\mathrm{P}_{4}$ in Group 2 and Group 3 differed non-significantly $(\mathrm{P}>0.05)$.The peak value of progesterone in Group 1 at day 13 was $(3.93 \pm 0.05 \mathrm{ng} / \mathrm{ml})$. The values of $\mathrm{P}_{4}$ in Group 1 at day $4,7,10$ and 13 differ significantly $(\mathrm{P}<0.05)$ from Group 2 and 3.

Table.1 Plasma blood urea concentration (Mean \pm SEM, mg/dl) in prepubertal buffalo heifers

\begin{tabular}{|c|c|c|c|}
\hline Day of Altrenogest Feeding & Group 1 (n=7) & Group 2 (n=7) & Group 3 (n=6) \\
\hline $\mathbf{1}$ & $7.15 \pm 0.73$ & $6.61 \pm 0.69$ & $7.11 \pm 0.34$ \\
\hline $\mathbf{4}$ & $7.24 \pm 0.42$ & $7.08 \pm 0.95$ & $7.23 \pm 0.32$ \\
\hline $\mathbf{7}$ & $7.22 \pm 0.33$ & $6.67 \pm 0.71$ & $7.05 \pm 0.24$ \\
\hline $\mathbf{1 0}$ & $6.81 \pm 0.54$ & $6.80 \pm 0.79$ & $6.98 \pm 0.31$ \\
\hline $\mathbf{1 3}$ & $6.11 \pm 0.49^{\mathrm{a}}$ & $5.52 \pm 0.54^{\mathrm{b}}$ & $7.22 \pm 0.33^{\mathrm{c}}$ \\
\hline $\mathbf{1 5}$ & $4.6 \pm 0.49^{\mathrm{a}}$ & $4.70 \pm 0.62^{\mathrm{a}}$ & $7.13 \pm 0.33^{\mathrm{b}}$ \\
\hline
\end{tabular}

Values bearing different superscripts $(\mathrm{a}, \mathrm{b}$ and $\mathrm{c})$ along the row differed significantly $(\mathrm{P}<0.05)$

Table.2 Plasma glucose concentration (Mean \pm SEM, mg/dl) in prepubertal buffalo heifers

\begin{tabular}{|c|c|c|c|}
\hline Day of Altrenogest Feeding & Group 1 (n=7) & Group 2 (n=7) & Group 3 (n=6) \\
\hline $\mathbf{1}$ & $57.21 \pm 0.60$ & $55.63 \pm 0.14$ & $57.3 \pm 0.28$ \\
\hline $\mathbf{4}$ & $58.45 \pm 1.43$ & $55.96 \pm 0.24$ & $57.13 \pm 0.28$ \\
\hline $\mathbf{7}$ & $58.83 \pm 1.53$ & $55.33 \pm 0.24$ & $56.81 \pm 0.44$ \\
\hline $\mathbf{1 0}$ & $59.01 \pm 1.58^{\mathrm{a}}$ & $56.53 \pm 0.28^{\mathrm{b}}$ & $56.81 \pm 0.35^{\mathrm{b}}$ \\
\hline $\mathbf{1 3}$ & $58.9 \pm 1.57$ & $56.8 \pm 0.38$ & $57.08 \pm 0.33$ \\
\hline $\mathbf{1 5}$ & $61.08 \pm 1.93^{\mathrm{a}}$ & $57.2 \pm 0.36^{\mathrm{b}}$ & $56.83 \pm 0.41^{\mathrm{b}}$ \\
\hline
\end{tabular}

Values bearing different superscripts $(\mathrm{a}, \mathrm{b}$ and $\mathrm{c})$ along the row differed significantly $(\mathrm{P}<0.05)$ 
Table.3 Plasma progesterone concentration (Mean \pm SEM, ng/ml) in prepubertal buffalo heifers

\begin{tabular}{|c|c|c|c|}
\hline Day of Altrenogest Feeding & Group 1 (n=7) & Group 2 (n=7) & Group 3 (n=6) \\
\hline $\mathbf{1}$ & $0.90 \pm 0.03$ & $0.89 \pm 0.01$ & $0.94 \pm 0.01$ \\
\hline $\mathbf{4}$ & $2.64 \pm 0.01^{\mathrm{a}}$ & $0.91 \pm 0.01^{\mathrm{b}}$ & $0.92 \pm 0.01^{\mathrm{b}}$ \\
\hline $\mathbf{7}$ & $3.15 \pm 0.06^{\mathrm{a}}$ & $0.88 \pm 0.01^{\mathrm{b}}$ & $0.91 \pm 0.01^{\mathrm{b}}$ \\
\hline $\mathbf{1 0}$ & $3.60 \pm 0.10^{\mathrm{a}}$ & $0.92 \pm 0.01^{\mathrm{b}}$ & $0.88 \pm 0.01^{\mathrm{b}}$ \\
\hline $\mathbf{1 3}$ & $3.93 \pm 0.05^{\mathrm{a}}$ & $0.98 \pm 0.01^{\mathrm{b}}$ & $0.82 \pm 0.01^{\mathrm{b}}$ \\
\hline $\mathbf{1 5}$ & $0.30 \pm 0.01$ & $0.40 \pm 0.01$ & $0.70 \pm 0.01$ \\
\hline
\end{tabular}

Values bearing different superscripts ( $a$ and $b$ ) along the row differed significantly $(\mathrm{P}<0.05)$

Table.4 Plasma estradiol concentration (Mean \pm SEM, pg/ml) in prepubertal buffalo heifers

\begin{tabular}{|c|c|c|c|}
\hline Day of Altrenogest Feeding & Group 1 (n=7) & Group 2 (n=7) & Group 3 (n=6) \\
\hline $\mathbf{1}$ & $33.39 \pm 0.36$ & $34.80 \pm 0.50$ & $33.71 \pm 0.29$ \\
\hline $\mathbf{4}$ & $30.93 \pm 0.32^{\mathrm{a}}$ & $28.42 \pm 0.44^{\mathrm{b}}$ & $34.34 \pm 0.48^{\mathrm{c}}$ \\
\hline $\mathbf{7}$ & $26.32 \pm 0.46^{\mathrm{a}}$ & $25.42 \pm 0.37^{\mathrm{a}}$ & $33.41 \pm 0.41^{\mathrm{b}}$ \\
\hline $\mathbf{1 0}$ & $34.6 \pm 0.29$ & $33.05 \pm 0.49$ & $33.60 \pm 0.44$ \\
\hline $\mathbf{1 3}$ & $36.27 \pm 0.40$ & $35.52 \pm 0.49$ & $33.86 \pm 0.56$ \\
\hline $\mathbf{1 5}$ & $40.04 \pm 0.59^{\mathrm{a}}$ & $37.22 \pm 0.58^{\mathrm{b}}$ & $33.63 \pm 0.36^{\mathrm{c}}$ \\
\hline
\end{tabular}

Values bearing different superscripts $(\mathrm{a}, \mathrm{b}$ and $\mathrm{c})$ along the row differed significantly $(\mathrm{P}<0.05)$

Table.5 Plasma estradiol - progesterone ratio (Mean \pm SEM) in prepubertal buffalo heifers

\begin{tabular}{|c|c|c|c|}
\hline Day of Altrenogest Feeding & \multicolumn{3}{|c|}{ EP Ratio \pm SEM } \\
\hline & Group 1 & Group 2 & Group 3 \\
\hline $\mathbf{1}$ & $20.21 \pm 0.25$ & $22.52 \pm 0.35$ & $21.8 \pm 0.28$ \\
\hline $\mathbf{4}$ & $11.70 \pm 0.11^{\mathrm{a}}$ & $10.36 \pm 0.18^{\mathrm{a}}$ & $21.07 \pm 0.29^{\mathrm{b}}$ \\
\hline $\mathbf{7}$ & $6.68 \pm 0.11^{\mathrm{a}}$ & $7.34 \pm 0.10^{\mathrm{a}}$ & $20.45 \pm 0.45^{\mathrm{b}}$ \\
\hline $\mathbf{1 0}$ & $10.94 \pm 0.07^{\mathrm{a}}$ & $11.41 \pm 0.15^{\mathrm{a}}$ & $20.99 \pm 0.64^{\mathrm{b}}$ \\
\hline $\mathbf{1 3}$ & $42.28 \pm 0.81^{\mathrm{a}}$ & $47.99 \pm 1.10^{\mathrm{b}}$ & $20.79 \pm 0.40^{\mathrm{c}}$ \\
\hline $\mathbf{1 5}$ & $82.62 \pm 1.42^{\mathrm{a}}$ & $69.01 \pm 2.21^{\mathrm{b}}$ & $21.11 \pm 0.43^{\mathrm{c}}$ \\
\hline
\end{tabular}

Values bearing different superscripts $(\mathrm{a}, \mathrm{b}$ and $\mathrm{c})$ along the row differed significantly $(\mathrm{P}<0.05)$

Fig.1 Plasma blood urea concentration (Mean \pm SEM, mg/dl) in pre-pubertal buffalo heifers at different days of treatment

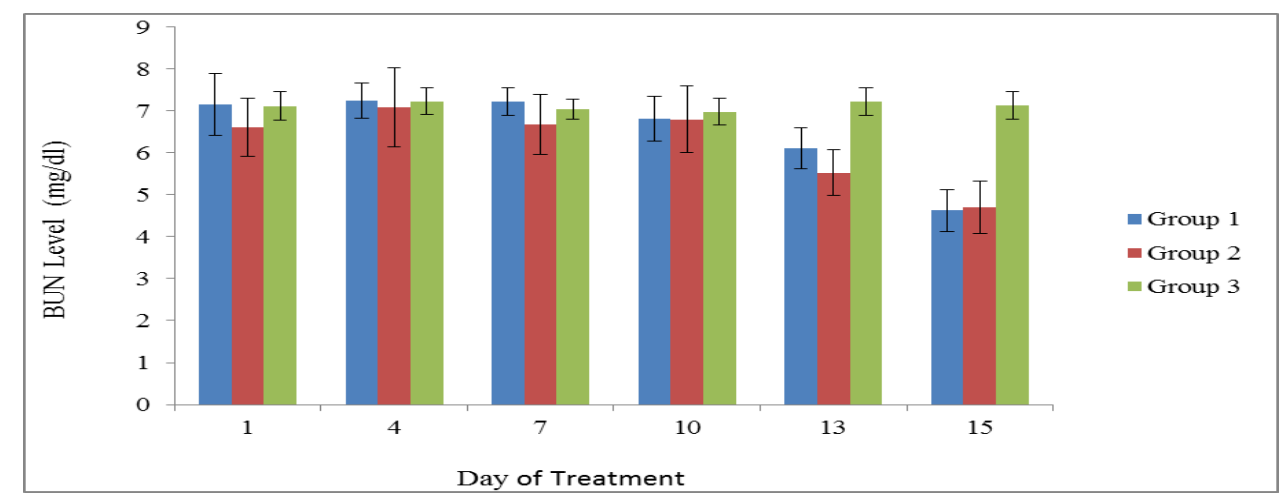


Fig.2 Plasma glucose Concentration (Mean \pm SEM, $\mathrm{mg} / \mathrm{dl}$ ) in prepubertal buffalo heifers at different days of treatment

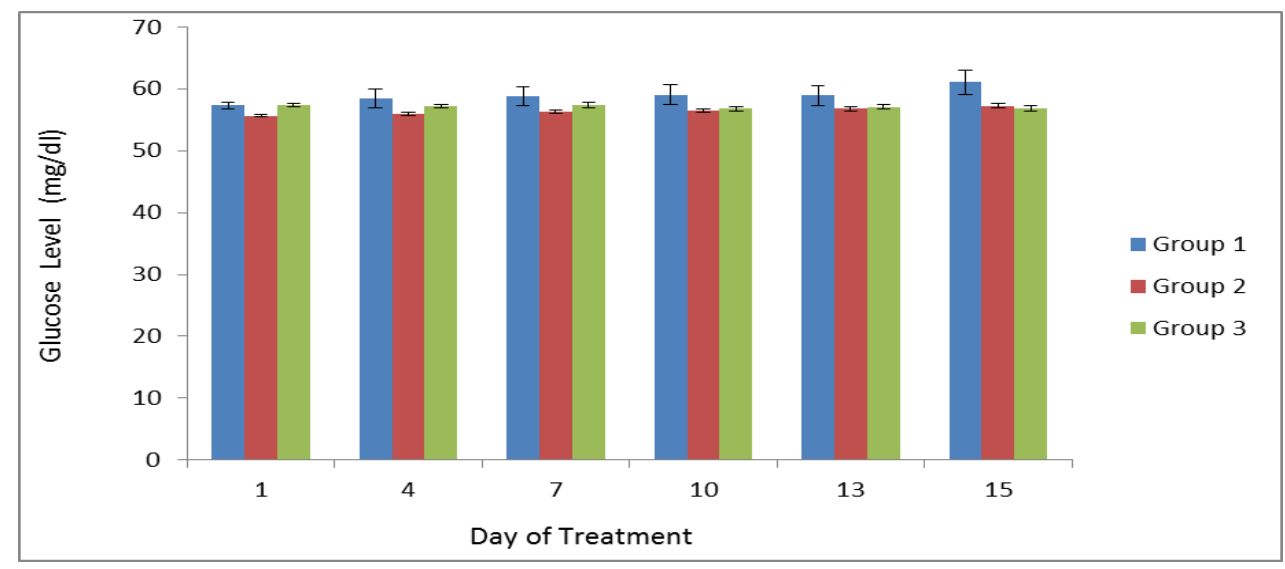

Fig.3 Plasma progesterone concentration (Mean \pm SEM, ng/ml) in prepubertal buffalo heifers at different days of treatment

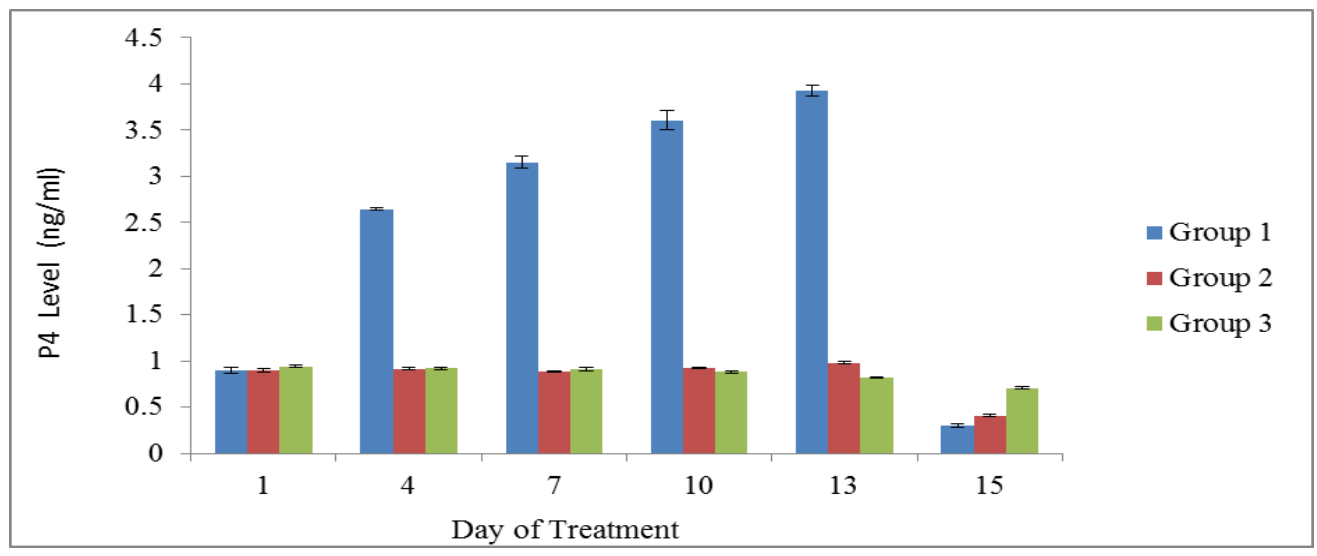

Fig.4 Plasma estradiol concentration (Mean \pm SEM, pg/ml)in prepubertal buffalo heifers at different days of treatment

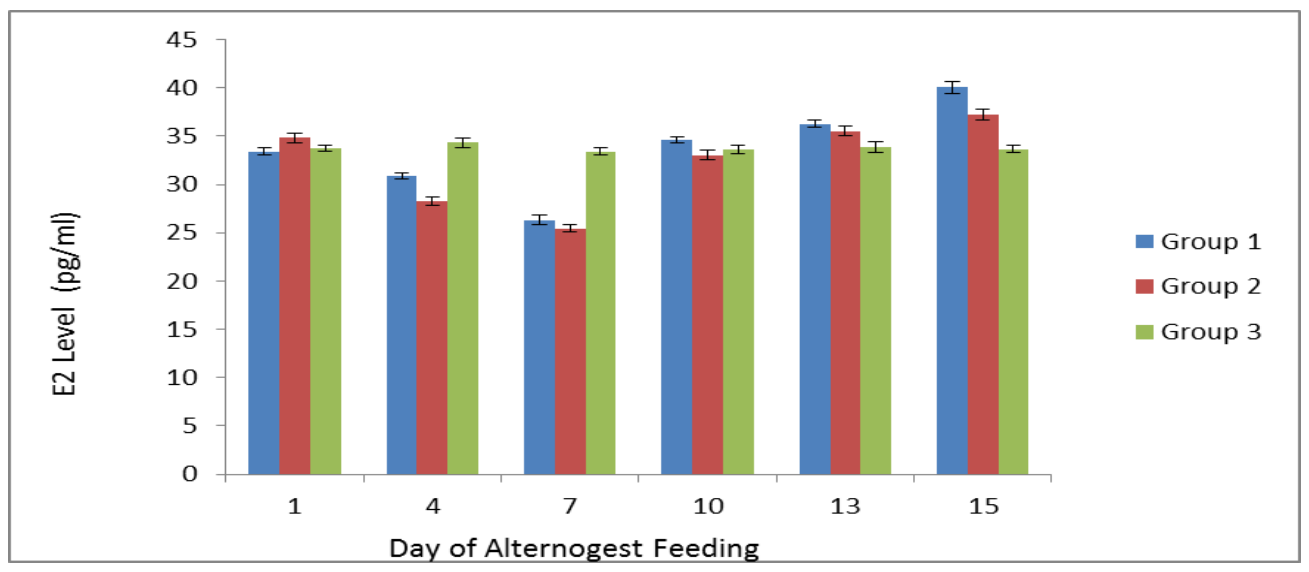


Fig.5 Plasma estradiol - progesterone ratio (Mean \pm SEM) in Group 1 prepubertal buffalo heifers at different days of treatment

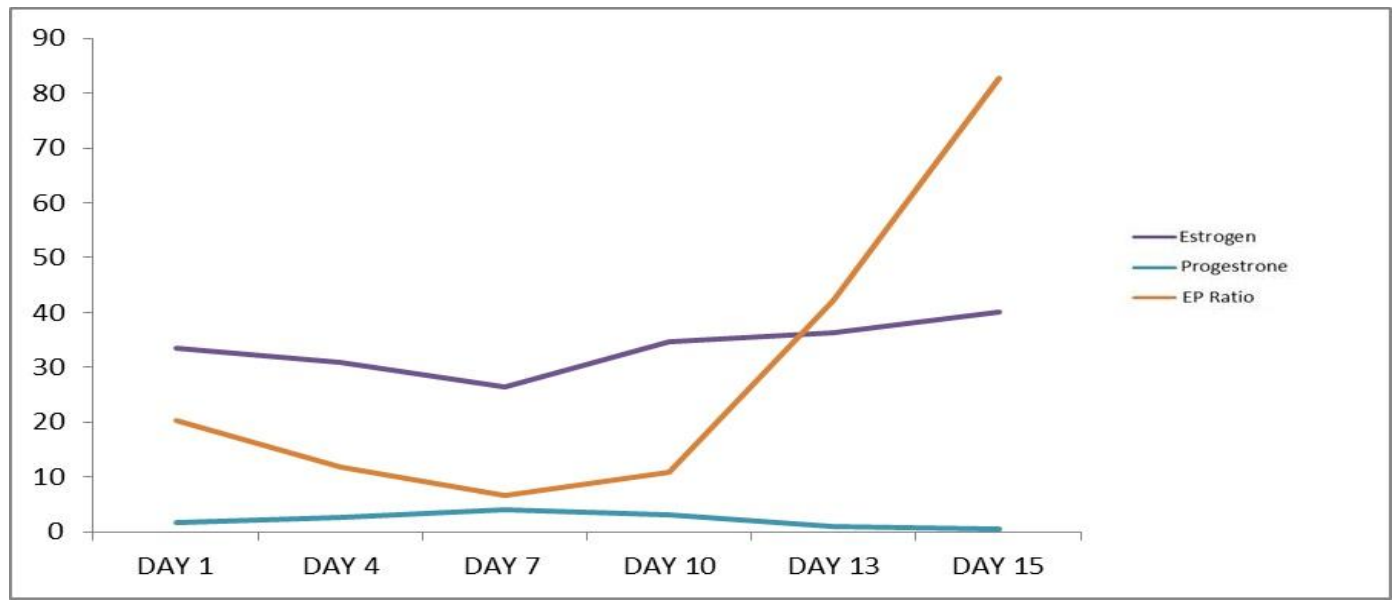

Fig.6 Plasma estradiol - progesterone ratio (Mean \pm SEM) in Group 2 prepubertal buffalo heifers

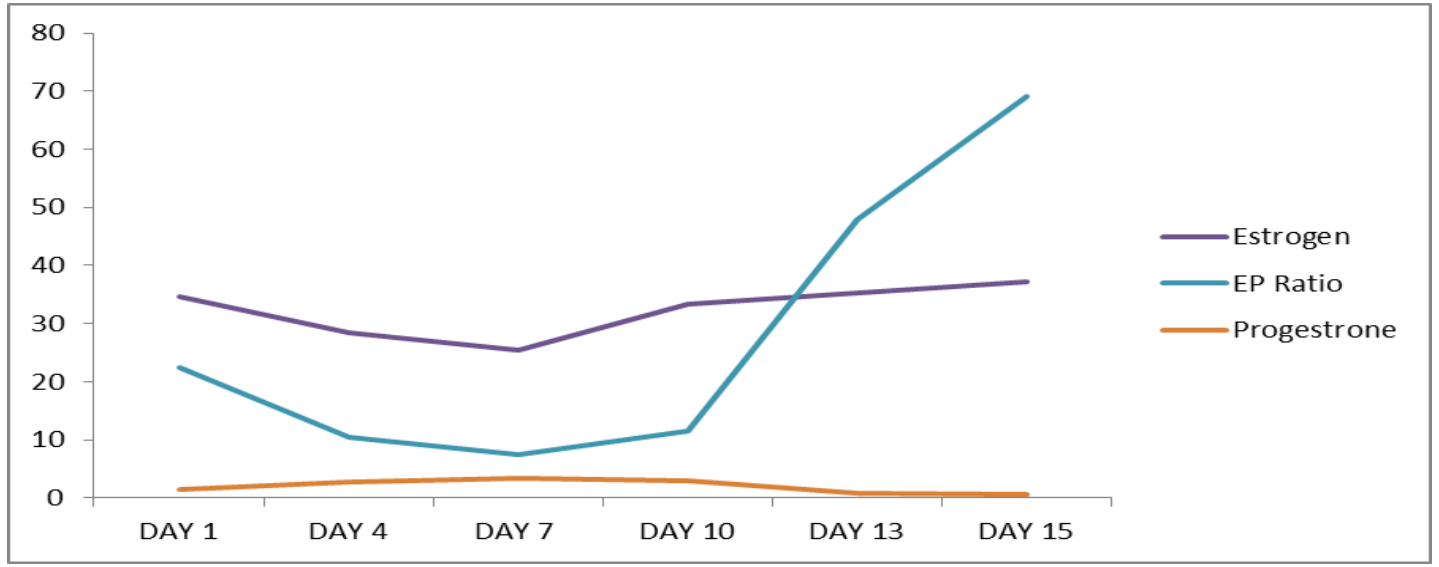

Fig.7 Plasma Estradiol - Progesterone ratio (Mean \pm SEM) in Group 3 pre-pubertal buffalo heifers

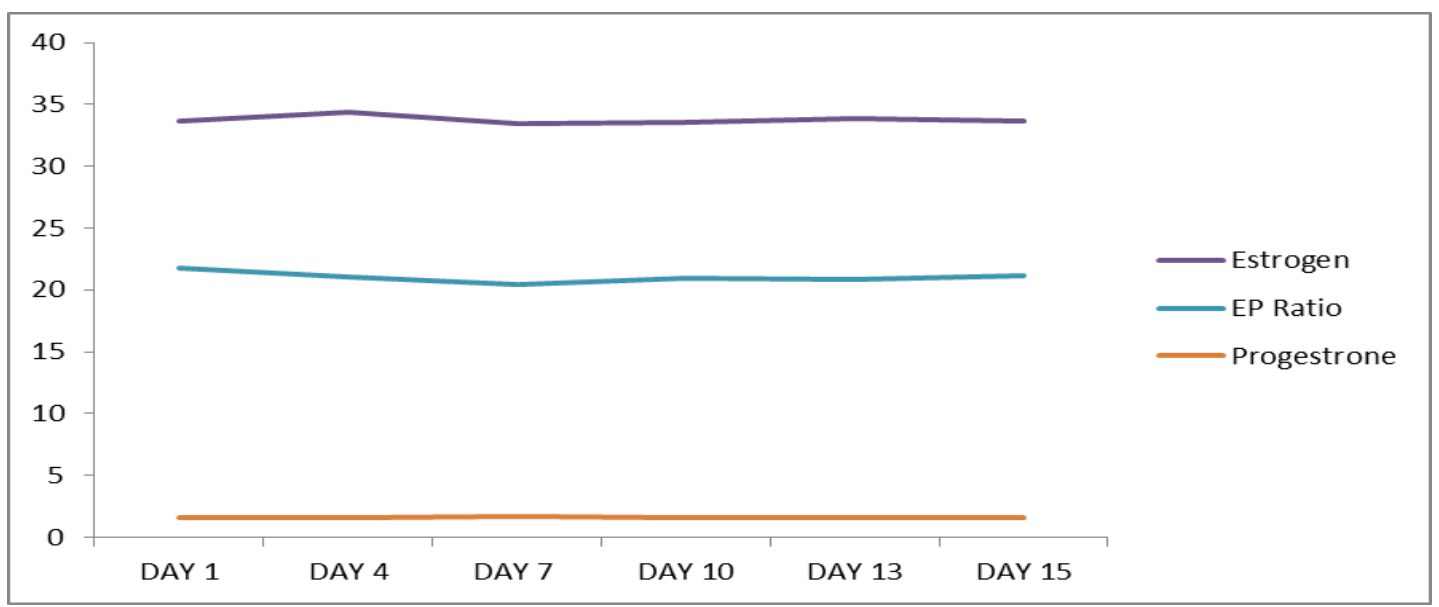




\section{Plasma estrogen profile}

Plasma $E_{2}$ profile in present study varied from $(26.32 \pm 0.46$ to $40.04 \pm 0.59 \mathrm{pg} / \mathrm{ml}, 25.42 \pm$ 0.37 to $37.22 \pm 0.58 \mathrm{pg} / \mathrm{ml}$ and $33.41 \pm 0.41$ to $34.34 \pm 0.48 \mathrm{pg} / \mathrm{ml}$ ) in Group 1, 2 and 3, respectively (Table 26).Comparing three Groups across day 15, Group 1 mean $\mathrm{E}_{2}$ concentration of $(40.04 \pm 0.59 \mathrm{pg} / \mathrm{ml})$ was significantly higher $(\mathrm{P}<0.05)$ than mean estradiol concentration of Group 2 (37.22 $\pm 0.58 \mathrm{pg} / \mathrm{ml})$ and Group 3 (33.63 \pm 0.36 $\mathrm{pg} / \mathrm{ml})$.Significant differences $(\mathrm{P}<0.05)$ were observed in mean $\mathrm{E}_{2}$ concentration over all Groups on day 15 but the differences were non-significant $(\mathrm{P}>0.05)$ across day 1 to 14 of the treatment. Henricks et al., (1973) also reported high $\mathrm{E}_{2}$ level in pregnant than in nonpregnant beef heifers following MGA treatment.

\section{Estrogen to Progesterone (EP) ratio}

EP ratio signifies comparative values of estradiol to progesterone levels. Rise in EP ratio symbolizes either increase in estradiol level or decrease in progesterone level, or both, and vice-versa.

In current study, Group wise EP ratio across the days of observation presents a deeper analysis of hormonal profile of pre-pubertal heifers. Day 1 values of Group 1 (37.56 \pm 1.46), 2 (38.75 \pm 0.82$)$ and $3(35.84 \pm 0.61)$ differed non-significantly $(\mathrm{P}>0.05)$. However, significant difference $(\mathrm{P}<0.05)$ was observed between Group 1 (134.20 \pm 7.33), 2 (91.74 \pm $3.55)$ and group $3(47.54 \pm 0.81)$ on Day 15 (Table 5). EP ratio across day 4,7 , and 10 post treatment were significantly $(\mathrm{P}<0.05)$ at lower side in Group 1 and 2 than in Group 3heifers, signifying the balance between estrogen and progesterone for growth of developing follicle on ovary as well as maintaining a balance at hypothalamic level by balancing the regulation of estrogen receptors and hence the negative feedback of estrogen.

Value of EP ratio increased largely on day 15 as compare to day 13 in Group 1 (9.26 \pm 0.16 to $134.20 \pm 7.33$ ) whereas such trend was at lower extent in Group 2 (36.09 \pm 0.76 to $91.74 \pm 3.55)$ and no such trend was observed in Group $3(41.29 \pm 0.33$ to $47.54 \pm 0.81)$, rather EP ratio of Group 3 remained almost same over complete stretch of period. Higher levels of EP ratio in Group 3 reveal the role of low progesterone in checking the early estrus in these heifers and hence delaying puberty.

Follicles have been subdivided according to their estrogen/progesterone ratio, because it has been well established that follicular activity is linked to a high ratio (Smith et al., 1996 and Thatcher et al., 1996). Estrogen/progesterone ratios in three day old follicles were always lower than one, suggesting that follicles were still in the common growth phase. In cattle, this phase lasts 3 days on average (Ginther et al., 2001) and extends from the beginning of wave emergence to the start of deviation. At this early stage, all follicles have the potential to become dominant (Ginther et al., 2003). An effort has been made to see whether the EP ratio can be taken up as a better indicator of optimum estrogen-progesterone levels for enhancing and optimizing the ovarian follicular growth and hence enhancing the puberty in buffalo heifers.

\section{References}

Arosh J A, Kathiresam D, Devannathan T G, Rajasundaram C R and Rajasekaran J. 1998. Blood biochemical profile in normal cyclical and anestrus cows. Indian Journal Animal science. 68: 1154-56.

Bashir M K, Khan M S, Lateef M and Akhtar P. 2009. Genetic and Phenotypic 
aspects of Age at First Calving of NiliRavi Buffaloes in Pakistan. Pakistan Journal of Zoology, 9:757-61.

Borghese A, Terzano G M, Barile V L and Parmeggiani A. 2005. Season and feeding level effects on onset of puberty in buffalo heifers. In: Proc. Fourth World Buffalo Congress, Sao Paulo, Brazil, 27-30 June: 525-27.

Clarence E F. 2004. The use of altrenogest to control reproductive function in beef cattle, A Ph.D dissertation submitted to the graduate faculty of Louisiana state university and agricultural and mechanical college, The Interdepartmental Program in Animal and Dairy Sciences.43-59.

Das G K and Khan F A. 2010. Summer anoestrus in buffalo-a review. Reproduction in domestic Animals Zucht hygiene, 45: 483-94.

Davis D L, Stevenson J S, Pollmann D S and Allee GL. 1987. Estrous and litter traits in gilts altered by altrenogest, flushing and pubertal status. Journal of AnimalScience. 64:1117-1126

Davis D. L, Knight J W, Killian D B and Day B N. 1979. Control of estrus in gilts with a progestogen. Journal of Animal Science 49:1506-09.

Evans ACO and Rawlings NC 1995. Effects of treatment with $\mathrm{LH}$ and FSH between 8 and 12 weeks of age on ovarian follicular development and puberty in heifers. Theriogenology 44:725-40.

Ginther O J, BegM A, DonadeuF X and Bergfelt D R. 2003. Mechanism of follicle deviation in monovular farm species. Animal reproduction science. 78(3-4): 239-57.

Ginther O J, Bergfelt D R, Beg M A andKot K. 2001. Follicle selection in cattle: relationships among growth rate, diameter ranking, and capacity for dominance. Biology of reproduction. 65(2): 345-50.
Henricks D M, Dickey J F and Niswender G D. 1973. Serum luteinizing hormone and plasma progesterone levels during the estrous cycle and early pregnancy in cows. Biology of Reproduction. 2: 34651

Hinglak S. 2013. Studies on reducing age at first calving by oral progesterone feeding in pubertal murrah buffalo heifers. M.V.Sc. Thesis, submitted to Guru Angad Dev Veterinary and Animal Sciences University, Ludhiana, India.

Jainudeen M R, Hafez E S E. 1993. Cattle and buffalo. In: Hafez, E.S.E. (Ed.), Reproduction in Farm Animals, 6th ed. Lea and Febiger, Philadelphia, USA, Pp. 315-329.

Mapletoft R J, Martinez M F, Colazo M G and Kastelic J P. 2003. The use of controlled internal drug release devices for regulation of bovine reproduction. Journal Animal Science 37(4):191-200.

Martinat-Botte, F, Bariteau F, Badouard B and Terqui M. 1985. Control of pig Reproduction in a breeding programme. Journal of Reproduction. Fertility. (Suppl.) 33:211-228.

Patterson D J, Kiracofe G H, Stevenson J S, and Corah L R. 1989. Control of the bovine estrous cycle with melengestrol acetate (MGA): A review Journal of AnimalScience 67: 1895-1906.

Peters A R. 1992. Endocrine manipulationtoxicological frontiers. Journal of Reproduction Fertility (Suppl.)45: 193201.

Ramadan TA, Sharma R K, Phulia S K, Balhara, A K, Ghuman S S and Singh I. 2015. Effects of melatonin and controlled internal drug release device treatment on blood metabolites of buffalo heifers during out-of-breeding season under tropical conditions.

Rauwa WM, Kanisb E, Noordhuizen-Stassenc EN, Grommersc FJ. 1998. Undesirable 
side effects of selection for high production efficiency in farm animals: a review. Livestock Production Science 56:15-33.

Shideler R K, Voss J L, Aufderheide W M, Hessemann C P and Squires E L.1983. The effect of altrenogest, an oral progestin, on hematologic and biochemical parameters in mares. Veterinary Hum Toxicology 25:250252.

Smith L, Olivera-Angel M, Groome N, Bhatia B and Price C. 1996. Oocyte quality in small antral follicles in the presence or absence of a large dominant follicle. Journal Reproduction Fertility. 106: 193-199.

Squires E L, Heesemann C P, Webel S K, Shideler R K and Voss J L. 1983. Relationship of altrenogest to ovarian activity, hormone concentrations and fertility of mares. Journal Animal Science 56:901-910.
Squires E L, Stevens W B, McGlothlin D E, and Pickett B W. 1979. Effect of an oral progestin on the estrous cycle and fertility of mares. Journal Animal Science.49:729-735.

Thatcher W W, De la SotaRL, SchmittE J, Diaz T C, Badinga L, Simmen F A and Drost M. 1996. Control and management of ovarian follicles in cattle to optimize fertility. Reproduction, fertility and development. 8(2): 203-17.

Turner D D, Garcia M C, Webel S K, and Ginther O J. 1981. Influence of follicular size on the response of mares to allyl trenbolone given before the onset of the ovulatory season. Theriogenology16:73-84.

Webel S K and Squires E L. 1982. Control of the oestrous cycle in mares with altrenogest. Journal Reproduction Fertility (Suppl.) 32:193-198.

\section{How to cite this article:}

Aulakh, A. S., Prahlad Singh, Gurpreet Singh, S. S. Dhindsa, M. Honparkhe and Arashdeep Kaur. 2020. Effect of Altrenogest Feeding in Prepubertal Buffalo Heifers Vis-A-Vis Plasma Estrogen-Progesterone Levels and Biochemical Profile. Int.J.Curr.Microbiol.App.Sci. 9(08): 2337-2347. doi: https://doi.org/10.20546/ijcmas.2020.908.268 